\title{
Mekanik Gözün Kaydı Olarak Maddi Dünya
}

\author{
Eyüp $\mathrm{AL}^{12}$
}

Öz

Kamera, teknolojik araç olarak dünyayla modern bir ilişki kurmakta; her mekânı ve her nesneyi kaydederek dönüştürmekte ve görselleştirmektedir. Bu makalede öncelikli olarak kameranın nasıl bir dünya yarattığı ve bu dünyanın modernlikle olan ilişkisi ele alınmaktadır. Ardından da kameranın hareket yetilerinin gelişimi irdelenmekte ve sinema tarihinin ilk dönemlerinde tiyatro seyircisiyle örtüşen sabit bir bakış açısına sahip olduğu görülmektedir. Ancak zaman içerisinde kameranın hareketlenmesi ile daha farkı bakış açıları yakalanmıştır. İtalyan tipi sahnenin ve perspektifin ortadan kaldırıması da kameranın hareket kazanması ile irtibatlı bir şekilde ele alınmaktadır. Makale boyunca nesne/araç merkezli bir bakıştan hareket edilmekte, kamera içerikten bağımsız bir biçimde tarihsel bir fenomen olarak incelenmektedir. Araç merkezli yaklaşımın karşılığı olarak mekanik gözün maddi dünyanın her köşesini kaydettiği görülmektedir. Bu tartışmalar eşliğinde makalenin son bölümünde Film Kameralı Adam filmi sinematografik unsurların maddi dünya ile olan irtibatı açısından incelenmektedir. Filmin analizinde kameranın gündelik hayata dâhil olması, bakış açılarının çoğalması, yakın ve uzak çekim gibi farklı sinematografik unsurların maddi dünyayı dönüştürdüğü gösterilmektedir. Makale boyunca kavramsal ve kuramsal çerçeveyi teknolojik determinizm oluşturmakta; tarihsel ve sosyolojik/toplumbilimsel çözümleme yöntemleri de birlikte kullanımaktadır.

Anahtar Kelimeler: Bakış açısı, Kamera, Mekanik Göz, Perspektif, Maddi Dünya.

1 Arş. Gör., Marmara Üniversitesi İletişim Fakültesi Radyo, Televizyon ve Sinema Bölümü. eeyupal@gmail.com ORCID: 0000-0003-1201-6299. 


\title{
Physical World as a Record of the Mechanic Eye
}

\begin{abstract}
Camera as a technological tool, establishes a modern relationship with the world; transforms and visualizes every space and object by recording. First of all, in this article, what kind of a world camera creates and its relationship with modernity is discussed. Then, the development of camera movement abilities is examined and it is seen that it has a fixed point of view that overlapped with theater audience in the early stages of cinema history. However, over time, different points of view were obtained by moving the camera. Elimination of the Italian-style scene and perspective is also addressed in connection with the movement of the camera. Throughout this article, an object/means centered perspective is used, and camera is examined as a historical phenomenon, regardless of content. In response to object centered approach, mechanical eye seems to record every corner of physical world. Accompanied by these discussions, in the last part of the article, "Man with a Movie Camera" is examined in terms of the connection of cinematographic elements with the world. In film analysis, it is shown that different cinematographic elements such as close-up and long shots, camera's involvement in everyday life, the increase of point of views transform physical world. Throughout the article, technological determinism forms the conceptual and theoretical framework; historical and sociological analysis methods are also used together.
\end{abstract}

Keywords: Point of View, Camera, Mechanic Eye, Perspective, Physical World.

\section{Giriș}

Bir kitle iletişim aracı olarak sinemanın nasıl bir dünya ve değişim yarattığına bakıldığında, insanın kendisiyle, nesnelerle ve genel olarak evrenle kurduğu ilişkinin görmek, kaydetmek ve kontrol etmek gibi niteliklere sahip olduğu görülmektedir. Modern bir araç olarak sinema, görme eylemi üzerinden insanın her şeyle kurduğu ilişkiyi dönüştürmekte; yaşam ve nesneler üzerinde yeni bir kontrol mekanizması olarak kullanılmaktadır. Mevcut makale dâhilinde ise sinema ve kamera açısından insan hayatında modernliğin neden olduğu değişimin izleri takip edilecektir. Sinemanın tarihi Batı merkezli tarihsel süreçten ayrı düşünülemeyeceği için içine doğduğu ve belirli değişimleri tetiklediği tarihsel ve sosyolojik koşullar ile birlikte irdelenecektir. Bu bağlamda sinema denildiğinde meselenin daha açık bir şekilde anlaşılabilmesi için modernlik ile ilişkisi kurulacaktır.

Dünyanın her yerinde, zaman ve mekân ayırt etmeksizin kendi varlığını icbar eden sinema, kısaca "nesnenin hükümranlığı" (Baudrillard, 2012a) denilen ve makalenin ana omurgasını teşkil eden teknolojik determinizmin, nesne ya da araç merkezli bakışı ile irdelenecektir. Teknolojik bir araç olan sinema, bir düşünme ve yaşama biçimi olarak modernliğin dünya çapında kabul görmesinde içerikten bağımsız biçimde katkı sağlamakta; herkesi, yeni görme biçimlerine aşina kılmaktadır. Modern dünyada insan içinde bulunduğu düzeni kavrama, açıklama ve değiştirme açısından çok ciddi 
araçlara sahiptir ve bu araçlardan bir tanesi olan sinemanın neden olduğu kırılmayı göstermek ve bir yandan da modernlikle olan uyumunu açığa çıkartmak makalenin temel amaçlarından bir tanesidir. Dil, anlatı, temsil ve içerik düzeyinde anti modernist bir tavır takınılsa bile, kameranın yani aracın doğasının modernliğe uygun oluşu nedeniyle maddi dünyayla kurulan ilişkiyi yeni görme biçimleri özelinde köklü bir şekilde değiştirdiği düşünülmektedir.

Sinemayı sanat olarak değil de bir kitle iletişim aracı olarak değerlendirmek onun hem içine doğduğu hem de dönüştürdüğü yapıyı anlamayı sağlayacaktır. Bu süreçte sinemanın tercih edilme nedeni ise 20. yüzyılın en iyi göstergelerinden biri olmasından kaynaklanmaktadır. Makalenin son bölümünde film incelenirken, araç merkezli metodolojik yaklaşımın bir gerekliliği olarak kameraya ve onun gelişen doğasına uygun biçimde sinematografik bir analiz gerçekleştirilmektedir. Bir araç olarak kameranın çekim ölçekleri ve hareketleri ile dünyayı yeni bir biçimde görmenin nasıl inşa edildiği ele alınmaktadır. Bununla birlikte tarihsel süreçteki teknolojik gelişimlere ve sosyolojik dönüşümlere de odaklanılmaktadır.

Makalede Film Kameralı Adam filminin seçilme nedeni makalenin iddialarıyla doğru orantılı biçimde kameranın hayata dâhil olmasında, hareket kazanmasında, bakış noktalarını çoğaltmasında ve tüm bunları çok erken bir tarihte gerçekleştirmesinde yatmaktadır. Film hikâyesinden ziyade yapısal olarak yani sinematografik açıdan nasıl bir dünya kurguladığı bağlamında incelenmekte ve tek tek filmler yerine bir bütün olarak sinemanın modernlikle uyumlu olan belirli bir yaşama, görme ve düşünme biçimi yaratmasına odaklanılmaktadır. Benzer bir olguyu Armand Mattelart'ın Gezegensel Ütopya Tarihi adlı metninde Georges Meliés'ye atfettiği ifadede bulmak mümkündür: "Elinizin Altındaki Dünya" (2005, s. 207). Meliés, Film Yapımevi için bastırdığı bu ilan ile sinemanın anlamını icat edildikten çok kısa bir süre sonra kavramış ve dünyanın kamera vasıtasıyla nasıl ele geçirildiğini vurgulamıştır. Bu bağlamda sinematograf, dünyayı yeni bir biçimde görmenin ve idrak etmenin aracı olmasına rağmen sinematograftan önce fotoğraf, maddi dünyayı görsel bir zemine çekmiştir.

Kamera çok farklı ve yeni bir görme biçimi yaratmış, sanatsal alanda resmin bir yükümlülüğü olarak addedilen "olanı olduğu gibi” resmetmeyi dönüştürmüştür. Susan Sontag'ın ifadesiyle resim sanatının gerekçi görüntüler oluşturma görevini fotoğraf devralmıştır (2011, s. 114). Dünyanın objektif gösterimi yağlıboyadan fotoğraf alanına geçmiş ve bugüne kadar alışılmış olan görme biçimlerini değiştirmiştir. Zaman içerisinde tekniğin ve rasyonalitenin gelişimi yeni bir bakış ve gerçeklik bilincini açığa çıkartmıştır. "Bunun sonucunda sanatta nesnelliğe doğru bir yönelim baş gösterdi ve fotoğrafın temelleri de bu yönelimle örtüştü” (Freund, 2008, s. 68). Fotoğraf makinesiyle görülen maddi dünya, insan gözüyle görülenden daha farklı olduğu için fotoğraf makinesi daha nesnel olduğu düşünülen bir görme biçimi yaratmıştır.

Fotoğrafın sahip olduğu gerçeklik, yağlıboyayı tamamen sanatsal bir alana iterken kendisini de teknik bir sürece indirgemiştir. Tarihsel açıdan "pozitivizm, fotoğraf makinesi ve sosyoloji birlikte büyüdüler" (Yaykın, 2011, s. 32). Fotoğrafı ve onun yeni görme biçimlerini anlamak için tarihsel ve sosyolojik bağlarını görmek gerekmektedir. 19. yüzyılın ilk çeyreğinde icat edilen fotoğraf, dönemin koşulları gereği öncelikli olarak 
sanatsal açıdan değerlendirilmeyip iktidarın kaydetme ve kontrol altında tutma aracı biçiminde kullanılmıştır. Toplumsal olguları ve dönüşümleri en iyi biçimde kayıt altına alabilecek bir araca duyulan gereksinim ve yağlıboyanın bu konudaki yeteneklerinin sınırlıığından ötürü fotoğraf açığa çıkan ihtiyacı karşılamıştır.

Fotoğraf, yağlıboyadan çok daha kuvvetli bir biçimde, sahiplik duygusunu arttırmıştır. John Berger'in Görme Biçimlerinde ifade ettiği gibi yağlıboya tabloda çok uzun yıllar boyunca resmedilen kadınlar, tarlalar, yemekler ve hayvanların hepsi, sahip olmanın bir göstergesi konumundadır (2012). Fotoğraf da benzer biçimde görüntülediği her şeyi sahip olunacak bir nesneye indirgediği için "fotoğraf toplamak, dünyayı biriktirmektir" (Sontag, 2011, s. 2). Dolayısıyla fotoğraf aracılığıyla görmek kontrol etmekle, nedensel bağlar kurmakla ve biriktirmekle ilişkili olduğu için dönemin anlayışıyla uyum göstermiştir. Fotoğrafın varlığına imkân tanıyan araç da modern kültürün bir ürünüdür. Derman'ın ifadesiyle tüm teknik görüntüler, bir aygıt yani apparatus tarafından üretilir; bu aygıt icat edildiği ve kullanıldığı kültürün bir parçasıdır (2010, s. 56-57). Modernliğin dünyayı yeni bir gözle ve bakışla görme arzusu belirli teknolojik araçların devreye girmesiyle neticelenmiştir.

Yukarıda kısaca değinildiği gibi teknolojik gelişmeleri modernliğin içsel ve vazgeçilmez bir unsuru olarak okumak yerine, modernliği, teknolojiyi var eden bir düşünme ve yaşama biçimi olarak değerlendirmek farklı okumalar ve fırsatlar sunabilir. Mesela John B. Thompson, Medya ve Modernite adlı metninde medyanın yükselişiyle modern toplumların yükseliş biçimlerinin birbirleriyle iç içe geçtiğini ve modern dünya anlaşılmak isteniyorsa medya iletişiminin de anlaşılmak zorunda olduğunu ifade etmektedir. İletişim, modernitenin kurucu unsurlarından bir tanesidir ve modern toplumlar anlaşılmak isteniyorsa iletişim medyasının gelişimine odaklanılmalıdır (2008, s. 9, 13-14). Modernliğin tarihi iletişim araçları üzerinden pek okunmadı; hâlbuki iletişim araçlarını göz ardı ederek modernliği anlamaya çalışmak eksiklikler yaratacaktır.

Benzer bir bakış açısını Armand Mattelart, İletişimin Dünyasallaşması adlı eserinde vurgulamaktadır. İletişimin uluslararasılaşması ve evrenselleşmesi hem Aydınlanma çağı hem de liberalizm ile ilişkilidir; haberin serbest akışı, ürünün ve işgücünün serbest dolaşımı ile alakalıdır. Demiryolları ve tren, ulus devletin ilerlemesinin ve endüstri devriminin göstergeleridir (2013, s. 13-22). İletişim ve ulaşım alanında yaşanan teknolojik gelişmeler modernliğin açıklanmasında farklı katkılar sunabilmektedir. Bu makale de benzer biçimde, kameranın ve sinemanın içine doğduğu modern dünyanın anlaşılmasında önemli bir araç olabileceği, özelde de kameranın göz ile kurduğu ilişkinin klasik perspektif tartışmalarına, fotoğraftan farklı bir biçimde hem de çok erken bir tarihte yeni görme biçimleri yaratarak katkı sağladığını göstermeye çalışmaktadır. Görme biçimlerine dayalı bu değişimin modern düşünceyle olan irtibatı açıklanarak, sinema ve modernlik arasındaki ilişkinin bir yönü ortaya konmaya çalışılacaktır. İnsanın "elinin altındaki dünya" olarak sinema, içinde yaşanılan dönemle bütünlük arz ettiği için modernliğin maddi dünyayla kurduğu ilişkiyi çok benzer bir biçimde yeniden ürettiği görülmektedir. 


\section{Modernliğin Anlamı ve Sinemanın Konumu}

Modern zamanların başlangıcı ortaçağ sonrasına veya takriben 16. yüzyıl başlarına denk gelmektedir. Modernlik kozmoloji, dini, bilimsel, felsefi, siyasal, kültürel, ontolojik ve epistemolojik açılardan geçmişten yani eski dünyadan büyük bir kopuşu ve yeni dünyaya geçişi ifade etmektedir (Bağce, 2004, s. 6). Modernlik klasik düzenden ve düşünceden uzaklaşarak, insanın özneleşme ve geriye kalan her unsurun bilinebileceği, parçalarına ayrılabileceği, incelenebileceği, tanımlanabileceği ve kontrol altına alınabileceği nesneleşme süreci olarak ifade edilmektedir.

Modern düşünme biçimi, klasik düşünme biçiminin her anlamıyla farklılaşmasıdır; özellikle doğa anlayışındaki dönüşüm ve bilime atfedilen önemle birlikte bu yaşanmıştır. Modern düşünce teleolojik bağlarından koparılıp mekanik bir düzleme çekilmiştir; mesela Newton, mekanik sistemine dayalı bir fizik kuramı inşa etmiştir. Modern düşünme ile birlikte eskiye güven kaybolmakta ve eski her anlamıyla sorgulanmaktadır. Modern bilimin zemini herkes tarafından kabul edilebilir ve yeniden üretilebilir olandır. Bu bağlamda gözlemlenebilir, görüsel olan, dolaysızca bilinebilir olan ve fenomenal olan esas alınarak her türlü bilgi bu zemine dayandırılmaktadır. Artık hakikate gözlem ve görüler üzerinden ulaşılmaktadır. Dolaysızca var olduğu iddia edilen bu gözlem önermelerinden hareketle bilimsel olanın inşası ve kuruluşu gerçekleştirilmektedir. Modernliğin çıkışı dolaysız bilgiyle ilişkilidir (Çitil, 2017). Dolaysız bilgi insan açısından bilinebilir olanın sınırını çizerek metafiziği elemekte ve aydınlanma düşüncesiyle uyumlu bir biçimde insanın içinde bulunduğu düzeni mutlak anlamda bilebileceği ama görülebilir, temas edilebilir ve test edilebilir olanın dışında kalanın da bilgisine sahip olamayacağı fikriyatına dayanmaktadır.

Modern dünyada düşünmek neredeyse test edilebilir bir olgudur ve nesnesi vardır. Test etmek sadece bilimsel bir zeminde gerçekleştiği için düşüncenin nesnesi ve yöntemi modern dönemde bir hayli daralmıştır. Bu durum metafiziğe ait tüm konuların Kant'la birlikte bilimsel araştırmanın dışında kalmasına ve tartışılmamasına neden olduğu için buna da kısaca metafiziğin elenmesi denilmiştir. Adorno ve Horkheimer açısından aydınlanmanın hedefi, insanları korkudan uzaklaştırmak ve efendi konumuna getirmektedir. Aydınlanma, dünyanın büyüsünü bozacak ve söylenceleri bilgi yoluyla ortadan kaldıracaktır. Bunun dışında her şeye ve özellikle de maddeye hükmedilecek; hesaplanabilir olmayan unsurlara kuşkuyla yaklaşılacaktır. Matematikleştirilmiş dünya inancıyla her türlü söylenceden de kurtulunacaktır (2010, s. 19, 22, 45). Bu düzen içerisinde her unsur ölçülebilir yani niceliğe dönüştürülebilir olmalıdır. Elde edilen verilerin ise gerçeğin en yalın hali olduğu düşünülmektedir.

Teolojik açıklamaların yerini bilimsel metotlar almaya başlamış ve artık modern döneme doğru geçiş hızlanmıştır. Tanrı her ne kadar bilimsel açıklamaların içerisinde yer alsa da eski belirleyici kuvvetini kaybetmekte ve dünya mekanik yasalar doğrultusunda çok daha kuvvetli bir biçimde irdelenmektedir. Yasanın önermeleri içerisine dâhil edilenler, insan açısından tamamen bilinebilir olarak kodlanan fenomenlerdir yani olgulardır. Modernlik fikriyatıyla ilişkili biçimde birçok teknolojik araç geliştirilmiş ve makalenin sınırlılıkları içerisinde inceleme konusu olarak bu araç kamera olarak tercih edilmiştir. Kamera gibi her teknolojik araç önceden belirlenmiş bir matematiksel dizge içerisinde 
çalışarak akli olanı ön plana çıkartmaktadır.

Modernlik çok güçlü biçimde akılcılaştırmayla ilişkilidir ve Batı düşüncesi akılcılığı bir adım öteye taşıyarak akılcı bir toplum yaratmak istemiştir. Akılcı toplumda akıl sadece bilimi yönetmez; aynı zamanda, insanların ve nesnelerin de akılcı biçimde yönetilmesini arzular. Bu modernlik yaklaşımı toplumu hesaplanmış bir mimari yapı olarak görmekte ve aklı araçsallaştırmaktadır. Klasik modernlik anlayışı, aklın özgürleşmesi ve devrimi olarak değerlendirilmektedir. Modernlik genel olarak çekidüzen vermekle, ticareti düzenlemekle, hukuku yaratmakla, geleneğe ve ayrıcalıklara karşı çıkmakla özdeşleştiği için tüm ikilikleri reddederek akılcı bir dünya yaratmaya çalışmaktadır (Touraine, 2016, s. 25-26, 49). Dolayısıyla modernlik, bireysel ve toplumsal hayatı kılcal damarlarına kadar etki altına almakta, bir yaşama ve düşünme biçimi olarak var olmaktadır.

On yedinci yüzyılın ortalarında şöyle inançlar vardı: Maddi dünya bilimsel araştırmaların birincil kaynağı oluyordu ve insan eylemleri, zihni ve teolojik açıklamalar konu dışı bırakılıyordu. Matematik gün geçtikçe belirli ölçümlere bağlanıyordu. Tabiat felsefesinin de matematik gibi mantığa dayalı olabileceği fikrinden hareketle gözlem ve deneyin önemi artıyordu. Dünyayı anlama sürecinde akla olan güven artıyordu (Trusted, 2018, s. 136-137). Fenomenal ve gözlemlenebilir olanın öne çıkması ile kameranın arasında çok güçlü bir ilişki vardır çünkü pozitivist inançlar doğrultusunda kameranın maddi gerçeği yani ele geçirilebilir olanı kayıt altına alarak saklayabildiğine ve tekrar tekrar gösterime sunabildiğine inanılmaktadır. ${ }^{3}$

Kitle iletişim araçları ve sinema bu bağlamdan hareketle okunduğunda, insanın dünyadaki konumunu belirleyen araçlar olarak ön plana çıkmaktadır. Sanatsal niteliklerinden ziyade teknolojik bir araç olarak sinema, dünyanın herhangi bir yerinde değil Batıda icat edilmiştir. ${ }^{4}$ Bunun nedeni ise çok açıktır çünkü dünyayı bir biçimde kavramanın ve açıklamanın kaynağı olarak ancak modern düşünce sinemayı icat edebilirdi. Sinemanın icat edilme aşamasında batıdaki tarihsel şartların olgunlaşması ve ekonomik imkânlar çok daha arka sıralarda yer almaktadır çünkü esas öncelik evreni, dünyayı ve insanı kavrama biçimindeki değişiklikte saklıdır. Bu süreçte sinema, modernliğin içsel dinamiklerini ve arzularını paylaşmakta; belirli tipte bir duyumsamanın ve sezişin ürünü olarak dünyayı Batılı gibi görmenin, hissetmenin, kavramanın ve belirlemenin aracı olmakta; "maddesel dünyanın ele geçirilmeye çalışılması"nda (Demir, 1994a, s. 2) çok önemli bir rol oynamaktadır.

Sinema hiçbir zaman sadece bireysel bir dönüşümün alanı olmamıştır; aksine, toplumsal düzeyde dönüşümlere neden olmuştur çünkü ele alınan gelişmeler tek tek insanları etkilese de bütüncül açıdan toplumun tamamına sirayet etmiştir ve etmeye de devam etmektedir. Fotoğrafın tarihinde değinilen "olanı olduğu gibi" ortaya koyabilme ve gerçeklik becerisi sinema için çok daha kuvvetli bir biçimde geçerlidir. Lumiére kardeşlerin belgesel nitelikli örnekleriyle birlikte makalenin inceleme bölümünde ele

3 Fotoğraf ve pozitivizm arasında daha detaylı ilişki için bkz. Freund, G. (2008). Fotoğraf ve Toplum. İstanbul: Sel Yayıncılık.

4 Burada Amerika ve Avrupa arasında herhangi bir ayrıma gidilmediği gibi, sinemanın önce Amerika'da mı yoksa Avrupa'da mı bulunduğu ile de ilgilenilmemekte; aksine, bu bloğun tamamı Batılı olarak değerlendirilmekte ve var olan ortak "düşünme ve yaşama pratiği”ne atıfta bulunulmaktadır. 
alınacak olan Vertov da gündelik ve toplumsal gerçekliğin belgesel niteliğinde aktarımı ile ilgilenmiştir. Dolayısıyla sinema açısından toplumsal düzeyi es geçmek mümkün olmadığı gibi bireysel olana yapılan vurgu hiçbir zaman için toplumsaldan ayrı ve bağımsız değildir. Bireysel düzlemde insanların hayatlarını, algılarını ve gerçeklerini dönüştüren kamera, benzer bir olguyu kaçınılmaz biçimde toplumsal düzeyde de gerçekleştirmektedir. Zaten sinemanın sanatsal bir araçtan ziyade kitle iletişim aracı olarak makale içerisinde ele alınması yukarıda ifade edilen amaç doğrultusundadır. Teknolojik determinist anlayışın doğal bir sonucu olarak araç, hem bireyi hem de toplumu yeni bir kavrama, görme ve düşünme biçimine itmektedir.

Aracın belirleyici rolü kısaca şöyle ifade edilebilir: "Teknolojiye çevremiz gittikçe nüfuz ettiğinden, dünya ile olan ilişkimiz, kontrol ettiğimiz ve irademize boyun eğen basit araçlardan ziyade, çoğunlukla, çevrelerini şekillendiren özneler gibi davranan nesneler tarafından biçimlendiriliyor" (Elsaesser ve Hagener, 2014, s. 322). İnsanın maddi dünyayı kontrol altına almaya çalıştığı süreçte araç da bir yandan insanı ve eylemlerini dönüştürerek kendi iktidar alanını yaratmaktadır.

Baudrillard'ın ifadesiyle insan, edilgen konumda bulunan nesneyi keşfetmemekte hatta nesne insanı keşfetmektedir; bugünlerde insanın nesneyi inşa ettiği gibi, nesne de insanı inşa etmektedir (2012a, s. 28; 2013, s. 53, 57). Nesne edilgen değildir; onun da kendine ait yapıp etmeleri ve tercihleri vardır. Öznenin hâkimiyeti yitirdiği ve nesnenin kontrolü ele geçirdiği bir süreç yaşanmaktadır (Baudrillard, 2005, s. 1819, 65-66). Nesne mutlak anlamda edilgen değildir ve yönlendirici anlamda belirli çıktılara sahiptir. Öznenin eylemleri ile nesnenin tercihleri arasında gidiş gelişler söz konusudur. Nesnenin hâkimiyeti ele geçirdiği yani etkin bir konum elde etmeye başladığı düşüncesini Baudrillard'ın diğer metinlerinde de bulmak mümkündür.

“... Nesne özneyi kırılıma uğratır ve bütün teknolojilerimizi kullanarak, kendi mevcudiyetini ve rastlantısal formlarını sinsice dayatır. Oyunun efendisi artık özne değildir, ilişki tersine çevrilmiş gibidir" (Baudrillard, 2012b, s. 39-40). Bir kez icat edilen herhangi bir araç, o andan itibaren insanın dünyasını sonuna kadar değiştirmektedir. Roland Barthes da benzer bir düşünceyi fotoğraf alanında ifade eder: Fotoğraf, özneyi nesneye dönüştürür (2011, s. 25). Dünyayı biçimlendirmek ve kontrol altına almak için icat edilen araçlar yani teknolojik aygıtlar, insanın dünyasını beklenmedik şekillerde dönüştürmektedir.

Bu bağlamda sinema, her türlü teknolojik araçla birlikte insanı ve onun tüm yapıp etmelerini şekillendirmektedir. Kamera aracılığıyla dünyayı kayıt altına alma yönündeki istek, dolaylı bir biçimde insanı, bilgisini ve dünyayla kuracağı ilişkiyi de değiştirmektedir. Sinema merkezi bir bakış açısından hareketle sadece insanların düşüncelerini değiştirmemekte; aynı zamanda dünyayı farklı biçimde kavramanın imkânını sunmakta ve bunu basit bir nesne olarak değil, özneleşerek gerçekleştirmektedir. Sinema kendinde bir evren yaratarak, kendisi dışındaki her şeyi nesneleştirerek görüntünün bir parçası kılar ve bakışa sunar. Kendi içinde yeterli olan bu sinemasal evren, maddi dünyaya ait her unsuru bütünün parçası boyutuna indirgeyerek öznenin gittikçe aygıtın kontrolü altına girdiği bir durum yaratır.

Sinema gibi teknolojik araçlar dünyadaki her unsuru kolaylıkla ulaşılabilir, bilinebilir ve 
kontrol edilebilir bir hale getirerek modernliğin bakışını sürdürerek tahkim etmektedir. "Sentetik dünya, yeni teknolojinin temsil biçimleri, onun kitle kültürü yeryüzü üzerindeki kontrol edilebilirlik potansiyelini artırmaktadı»" (Süalp, 2004, s. 256). İnşa edilmiş ya da kurgulanmış bu dünyanın kökleri çok açık biçimde modernlikle ilişkilidir çünkü organik dünya görüşünün yerini mekanik dünya görüşü almıştır. Bu dünya görüşünde evrenle mekanikliğe uygun biçimde yapay ve eklektik ilişki geliştirildiği için her şeyin hesaplanabildiği bir düzende yaşanmaktadır. Bu yapı içerisinde herkes ve her şey belirli roller ve görevlerle tanımlanmakta, anlamını ve değerini "mekanizasyon süreci" (Mumford, 1996, s. 363) içerisinde elde etmekte; mekanik düzenin performansını artıracak ara elemanlara dönüşmektedir.

Yaklaşık olarak iki buçuk yüzyıldır fizikçiler, dünyaya mekanik bir bakışla baktılar. Onların düşünceleri genel itibariyle Newton'un matematiksel teorisine, Descartes'ın felsefesine ve Bacon'ın ortaya koyduğu metodolojiye uygun düşecek biçimde gelişmiştir. Madde tüm var oluşun köküdür ve maddi dünya bir makinadır. Bu kozmik makine belirli parçaların bir araya getirilmesinden oluşmaktadır. Karmaşık olaylar açıklanırken onu oluşturan yapıtaşlarına inildi ve mekanizma incelendi. Tüm diğer bilimler de klasik fiziğin mekanik ve indirgemeci yaklaşımını kabul etmiştir (Capra, 2018, s. 55). Bu bakış on altı ve on yedinci yüzyıllarda açığa çıkmış, organik ve canlı evren fikrinin yerini makine tarzındaki bir evren almıştır. Rasyonel öznenin var olmaya başladığı, teolojik tasarımların yerini mekanik dünya görüşüne bıraktığı, aydınlanma ile her şeyin açıklanabilir olduğuna inanılan bir geçiş süreci yaşanmıştır. Artık her şey belirli matematiksel ilkeler etrafında anlaşılabilir ve açıklanabilir bir noktaya indirgenmiştir.

Söz konusu sinema olduğunda belirli başat ayrımların ön plana çıktığı görülmektedir. Genel olarak ana akım/popüler sinema ve sanat sineması diye bir adlandırma mevcuttur. Bu ayrım farklı kişilerce farklı şekillerde de yapılmaktadır. Mesela Dudley Andrew, Büyük Sinema Kuramları kitabında sinemayı kendi içerisinde biçimci ve gerçekçi sinema olmak üzere ikiye ayırmaktadır (2010). Ancak bu ve benzeri ayrımlar meselenin özüyle ilişkili değildir çünkü sinema yapma biçimlerine ya da anlayışlarına dayalıdır. Hâlbuki bu makalede sinema denildiğinde farklı sinema yapma pratiklerine referans verilmemekte; aksine, sinemanın ve özelde de kameranın teknolojik araç olmalarından ötürü maddi dünyayı kuşatmaları ve bunu yaparken de mekân içerisindeki konumlanışları itibariyle farklı bakış imkânlarını açığa çıkartmaları irdelenmektedir.

Burada elde edilen sonuçlardan bir tanesi yağlıboya tabloda, perspektif ile başlayan süreçte öznenin konumunun ve bakışının önceden belirlenmesidir. Öznenin, bakışa dayalı özgürlüğü yok edilerek tabloyla kuracağı ilişki yönlendirilmektedir. Bu olgu zaman içerisinde radikalleşerek fotoğrafta açığa çıkmış ve bakış tamamen önceden belirlenerek sabitlenmiştir. Bir yandan da teknolojik bir araç olarak kameranın devreye girmesiyle öznenin kendisine yönelen bakış pratikleri de söz konusu olmuştur. Bu tarihsel olgu sinemayla birlikte gelişimini sürdürmüş ve bakışın zaman içerisindeki devamlılığını sağlayabilmiş ve gerçeklik duygusunu artırmıştır. Dolayısıyla sinema, mekanik dünya görüşünün yansıması olarak fotoğraftan daha farklı kavrama, bakma, bilme ve deneyimleme biçimlerine neden olmaktadır. Bu açıdan sinema tarihine bakıldığında kırılma yaratan olgulardan bir tanesi kameranın teknolojik açıdan gelişerek hafiflemesi ve hareket kabiliyetinin artmasıdır. Böylece seyircinin bakış açıları/noktaları 
çoğalmakta ve gerçekliği farklı veçheleriyle birlikte kavrama imkânı artmaktadır.

\section{Hareketli Kamera İle Bakıș Açılarının Çoğalması}

Kameranın icat edilmesi ile dünyanın her yerine ulaşabilmesi ve istediği görüntüyü kaydedebilmesi arasında zamansal bir farklılık söz konusudur. Ancak zaman içerisinde kameranın hareket yetilerinin gelişimi nedeniyle kamera ile göz eşleştirilmiş; insanın bakış pratikleri kamera sayesinde hız ve akışkanlık kazanmaktadır. Rudolf Arnheim ise insan gözü ile kamera arasında kurulan olumlu paralellikleri kabul etmez ve gözün görüş alanının sınırsızlığına, sinema görüntüsünün ise daima sınırlı olduğuna vurgu yapar. Kamera vasıtasıyla sunulan sınırlı görüntü mekânı süreksizleştirirken, mekân içerisinde istenildiği gibi hareket edilmesini de engeller. İnsan gözü özgürce oynatılabildiği için insanın görüş alanı sınırsızdır ama film görüntüsü mutlak biçimde sınırlıdır. Bu sınırlar içerisinde bazı şeyler görünürken bazı şeyler de dışarıda kalmaktadır (Arnheim, 2010, s. 32, 64). Sinema, insanı kameranın bakış açısıyla, görme ve algılama biçimiyle ilişkilendirdiği için kamera daima sınırlı bir bakış alanı yaratır ve gözün özgürlüğüne sahip değildir. Kamera, mekânı da ister istemez parçalı hale getirerek onun bütünlüğüne zarar vermekte; insanın mekân içerisindeki eylemlerini kısıtlamakta ve kadrajın izin verdiği ölçüler içerisinde çerçevelemektedir.

Çerçevelenmiş herhangi bir nesne, zorunlu olarak bir bakış açısından hareketle sunulduğu için objektif yeniden üretim söz konusu olamaz. Normal algının perspektifi sinemadan farklıdır çünkü bakışın alışkın olduğu düzeltmeler yoktur. Sinematografik çerçevede görüntünün sınırları varken, insanın bakışında doğal bir sınırsızlık söz konusudur (Pezella, 2006, s. 49-50). Kamera, insanın bakışını yönlendirerek nesnesini bir çerçeve içerisinde parçalı hale getirmekte; önceden belirlenmiş ve sınırlandırılmış bir bakış pratiği yaratmaktadır. Normal şartlar altında göz, kişinin tercihleri doğrultusunda hareket ederken, sinemada kamera vasıtasıyla bir bakma biçimine yönlendirilmektedir. Bu bağlamda Arnheim'ın ifade ettiği gibi göz ile kamera yapısal nedenlerden ötürü benzer niteliklere sahip değildir. Tüm bu zıtlıklara rağmen kameranın gelişen doğası maddi dünyayı olabildiğince kayıt altına almaktadır.

Makalenin başında da vurgulandığı gibi insan kamera vasıtasıyla yeryüzüne hükmetmeye ve onu eksiksiz biçimde kaydetmeye çalışır; bunu da önceden belirlenmiş bir form içerisinde yapar. Kamera bu süreçte gündelik hayatın her yerine ve her anına dâhil olduğu için kameranın kuşatamadığı herhangi bir şey yoktur. Kameranın kuşatıcı konumunun anlaşılabilmesi için Rönesans perspektifi ile sinema tarihinin ilk dönemlerinde çekilmiş filmler arasındaki ilişkiye bakmak gerekmektedir ama öncelikli olarak perspektif tanımlanmalıdır.

Perspektif 14. yüzyılda Batıda ortaya çıkan yeni dünya görüşüyle ilişkili olarak dünyayı teatral bir seviyeye indirgemiştir. Perspektife dayalı temsil, gerçeklik ve sorumluluk duygusuna zarar vermiş; yaşamın eylemden uzaklaşarak gösteriye dönüşmesine neden olmuştur (Florenski, 2011, s. 61, 75, 78). Dünyanın izlenebilirliğe dayalı bu yeni temsili, bakışı ve seyretmeyi ön plana çıkartmıştır. Kamera ve sinema da seyre dayalı bu yeni durumu perçinlemiştir. 
Rönesans'ta merkezi perspektifin amacı sadece görünenleri değil görünmeyenleri hatta her şeyi kontrol altında tutmaktır. Bu ehlileştirme sürecinde bakan kişi, merkezi konuma yerleşmekte, egemenlik kazanmakta ve geriye kalan şeyler de bakışı tatmine zorlanmaktadır (Sayın, 2013, s. 16). Modernliğin insana ve bakışına atfettiği merkezi konum kendisi dışındaki her şeyin nesneleşmesine açıkça neden olmaktadır. Evren, insan bilgisinin nesnesi haline getirilerek, bilinebilir ve kontrol edilebilir bir düzleme çekildiği için benzer bir durum bakış ve perspektif alanında da geçerlidir. "... Dünyanın perspektifle yapılan temsili, bir teknik çizim yönteminden başka bir şey değildir" (Florenski, 2011, s. 124). Teknik açıdan resmedilebilir seviyeye indirgenen dünya ve nesneler artık insanın aklı aracılığıyla bilgisine sahip olabileceği ve seyredebileceği bir unsur haline dönüşmüştür.

Perspektifle birlikte Ortaçağ'ın mekân anlayışı daha mekanik, ölçülebilir ve geometrik niteliklere dönüşmüştür. Bu süreç nesneye ve mekâna belli bir açıdan bakmaya, bakışı sabitlemeye ve yüceltmeye neden olmuştur (Özçınar, 2009, s. 91). Perspektifte mekânı kontrol ve terbiye etme sürecinde bakışın rolü ve konumu önem arz etmektedir. Harvey'e göre de perspektif ile yapılan haritalar soğuk, mesafeli, geometrik ve sistematik mekân anlayışının doğmasına neden olmuştur (Harvey, 2014, s. 272-274). Bir mekân olarak dünya, bakışa matematiksel olarak açılmakta ve seyrin nesnesi haline dönüşmektedir. Bakışa merkezi önem atfedilmesinin ardından mekân ve nesne, asli varlığını kaybedip gözün uzantısı ve ele geçirdiği bir yer haline gelmektedir. İnsanın özneleşen ve merkezileşen konumu kendini perspektif çiziminde en iyi şekilde göstermekte; insanın durduğu yer bakışını, bakışı da tüm nesnelerle kurduğu ilişkiyi belirlemektedir.

Bu bağlamda perspektifte her şey bakan kişinin görüşüne göre düzenlenmekte ve tek bir göz, tüm nesneler dünyasının merkezi konumuna gelmektedir (Berger, 2012, s. 16). Dolayısıyla perspektifi ve perspektif kullanımını sanat alanındaki basit bir yenilik olarak değerlendirmek söz konusu olamaz; aksine, perspektif, modern öznenin evrenle ve daha özelde de nesneyle kurduğu iktidar ilişkisinin yansımasıdır. Perspektif, evreni ontolojik bağlamlarından kopartıp, ölçülebilir bir niceliğe indirgemeyi sağlamış bir standarttır. Bu düzenleme mantığı çerçevesinde her şey resmedilmekte ve belirlenmiş bir bakışa sunulmaktadır. Perspektif bakışı sınırlayan bir gelişme olmakla birlikte dünyayı ve toplumu, fiziksel ve matematiksel ilkeler etrafında düşünmenin ve algılamanın boyutlarını açığa çıkarmıştır.

Rönesans perspektifi tek bir insan gözünü ve onun hareketsizliğini merkeze alarak bakan kişiyi de hareketsiz bir konuma yerleştirmiştir. Rönesans seyircisinin hareketsizliği sinemanın ilk yıllarıyla örtüşmektedir. Filmler dördüncü duvar olarak kamerayı ve seyirciyi kabul ederek çekilmiş ve hala birçok film bu mantık doğrultusunda çekilmektedir. Filmler sabit bir mesafeden çekildiği ve kamera hareketsiz olduğu için perspektif de değişmiyordu. Sinemanın bu ilk sınırlılıkları Rönesans ressamlarının sınırlarını anımsatmaktadır. Resimde Kübizm bu olguyu kırarak birçok bakış noktası yaratmış ve özneyi nesne etrafında farklı konumlara yerleştirmiştir. Böylece nesne farklı görünüşlere sahip olmakla birlikte hareket eden canlı bir varlığa dönüşmüştür. Benzer bir durum sinemada da kameranın hareketlenmesi ve farklı uzaklığa sahip merceklerin kullanılmasıyla yaşanmıştır. Kameranın hareket kazanması, gündelik hayat içerisindeki seyircinin konumuyla daha iyi örtüşmekte ve farklı bakış noktaları 
yaratmaktadır. Mekânın bütünsel bir yapı olarak kavranabilmesinde, mekân içerisindeki farklı bakış noktalarının çoğaltılması yer almaktadır (Demir, 1994c, s. 109110). Perspektifin merkezi bakışı ile sinemanın başlangıç aşamasında kameranın konumu arasında belirli paralellikler kurulduğu takdirde kameranın hem kesmeler hem de konumundaki değişimler ile bakış açılarını ve yeni görme biçimlerini nasıl yarattığı tarihsel bir bütünlük içerisinde gösterilebilecektir.

Bu açıdan sinema tarihinin ilk filmlerine bakıldığında kameranın konumu vasıtasıyla bakışın ve mekânın nasıl sabit bir biçimde ele alındığı rahatıkla görülmektedir. Lumiere Kardeşler'in 1895 yılında çektiği Trenin Gara Girişi adlı filminde, kamera sabit bir noktadadır ve hiç kesme yapılmadan trenin gara girişi genel çekimle ${ }^{5}$ gösterilmektedir. Garda bekleyen kalabalık insan grubu trenin gelişi ile birlikte yavaşça trene binmeye başlamakta ve film de böyle bitmektedir. Filmin süresinin bir dakikanın altında olması nedeniyle yoğun bir hikâye anlatımı söz konusu değildir. Ancak Trenin Gara Girişi'nde önemli olan nokta kameranın hiç hareket etmeyerek ve kesme yapmadan sabit bir noktadan mekânı kuşatmasıdır. Kameranın fazla ağır olması ve kısa süreler içerisinde yerinden oynatmanın çok zor olması nedeniyle hem kamera hem de bakış açısı sabit bir yerdedir. Bu süreçte bakışın hareketlilik kazanması ancak kameranın teknik yeterliliklerinin artması ile ilerleyen zamanlarda elde edilebilmiş bir özelliktir. Kameranın, insanın bakışı ile örtüşmesinden dolayı mekânla ve nesneyle kurulacak ilişkiyi belirlediği açıktır. Kameranın hareket edemiyor oluşu insanı da hareketsiz kıldığı için her şeye sabit bir noktadan bakmak zorunda kalınmıştır.

Benzer bir durum Meliés'nin 1902 yılında çektiği Aya Yolculukfilmi için de geçerlidir. Film bir grup insanın, özellikle de astrologların önemli bir konuyu tartışmasıyla başlamaktadır. Tartışma boyunca kamera nesnel çekimde kalarak 4. duvarı oluşturmaktadır. Klasik İtalyan tipi tiyatro sahnesine ait bir kavram olarak 4. duvar sinemada da kabul görmekte ve seyircinin konumu genel olarak oraya hapsedilmektedir. Mekânsal geçirgenlik hiç yoktur; oyuncular ve seyirciler birbirlerinden ayrı dünyaların parçası olarak var olmaktadırlar. Kamera da hiç hareket etmeyerek, olayları nesnel çekimle tiyatro seyircisinin konumu gibi karşıdan sunmaktadır.

Aya Yolculuk filminde kameranın konumu bu temel kabuller üzerinden ilerleyerek, hep aynı noktadan olayları ve mekânı kuşatmaktadır. Kameranın açısı film boyunca hiç değişmemekte; kesmeler vasıtasıyla sahneler ilerlemektedir. Aya fırlatılan roket sahnesinde de ayın görüntüsü nesnel çekimle sunulurken, ayın büyük bir hızla kameraya yaklaştığı görülmektedir. Artık insanlar aya varmıştır ve bu andan itibaren ayda bir süre var olmaya başlarlar. Bu süreçte kameranın konumu hala aynıdır ve

5 Çekim ve plan kavramları arasında bazen bir farkııık varmış bazen de yokmuş gibi kullanıldığı için bunun tarif edilmesi gerekir. Çekim (shot) kelimesi bir kareyle ya da sahnenin bir parçasıyla ilişkili olan en küçük birimdir ve kameranın bir kez çalıştırılmasıyla elde edilir. Tercümelerde ya da diğer metinlerde bazen çekim bazen de plan olarak kullanılmaktadır. Mesela Nijat Özön'ün Sinema Sanatına Giriş (2008), Mascelli'nin The Five C's of Cinematography (1965) kitaplarında çekim kelimesi kullanılırken; Brown'ın Sinematografi: Kuram ve Uygulama (2014) metninde plan kullanılmıştır. Makale içerisinde ise genel kullanıma uyularak çekim kelimesi tercih edilmiştir. Genel kabul çekimlerin sahneyi, sahnelerin sekansları, sekansların da bir filmi oluşturduğu yönündedir. Ancak bazen de planların çekilmesi ile sahnelerin oluşturulduğu düşünülmüş ve çekim sadece filme çekmek yani sahneyi çekmek gibi fiil anlamında kullanılmıştır. Çeviri metinlerde de çevirmenin diline uygun biçimde çekim ya da plan kullanıımıştır. Ancak onun dışında genel olarak yakın plan yerine yakın çekim; boy plan yerine de boy çekim denmiştir. 
dördüncü duvar olarak klasik yerini kaybetmeden film ilerlemeye devam etmektedir. Ayda uzaylılarla yaşanan tartışmalardan sonra astrologların kaçarak dünyaya geri gelmeleriyle film biter. Burada önem arz eden husus film boyunca kameranın konumu değiştiril(e)mediği gibi farklı çekim ölçekleri de kullanılamadığı için seyircinin bakış açısı nesnel kamerada sabit kalmıştır.

Nesnel kamera (objective camera), olaya bir gözlemcinin gözleri ile bakmaktadır. Tarafsız bakış açısı ile seyircinin görüş noktasını oluşturmakta; bazen de seyircinin bakış açısı olarak adlandırılmaktadır. Sahne, nesnel kamerada herhangi bir kişinin bakışından verilmediği için kişisel değildir. Bu süreçte oyuncular kamera yokmuş gibi davranmakta ve objektife bakmamaktadırlar (Mascelli, 1965, s. 13-14). Nesnellik açısından düşünüldüğünde filmin bir tiyatro sahnesindeki gibi çekildiği ve tiyatro seyircisinin konumuyla kameranın konumunun, dolayısıyla film izleyicisinin de aynı şekilde kurgulandığı görülmektedir.

Meliés filmin dekorlarını tiyatro sahnesindeki gibi hazırlamış ve filmi de öyle çekmiştir. İlk filmlerde kamera teknik yetersizliklerden ötürü hareketli değildir ve seyircinin konumu yani bakış açısı sabittir. Trenin Gara Girişi'nde kesme yokken Aya Yolculuk ile mekânda hareketlilik kesmeler vasıtasıyla sağlanmaktadır. Ancak kamera hala sabit bir noktada kalmakta ve seyircinin mekân içerisindeki konumu film boyunca değişmemektedir. İlk defa farklı çekim tarzları kullanılarak kameranın hareketsizliği aşılmaya çalışılmış ve eylemlerin üst üste bindirilmesiyle mekân belirli ölçüler içerisinde hareket kazanmıştır. Kamera hareketsiz olmasına rağmen mekânda bir hareket yanılsaması yaratılmıştır. Aya Yolculuk filmi sinema tarihi içerisinde farklı ilkleri gerçekleştirmiştir: Film, setin ve kostümün kullanılarak bir dünya yaratılmasına katkı sağladığı gibi film dilinin, anlatının ve hikâyenin ilk örneklerinden biri olmuştur. Sinemayı özel efektlerle birlikte görsel bir şölen olarak sunmuştur. Anlatıda, olanın olduğu gibi aktarımı yerine kamera, yavaşlatılmış çekim ve üst üste bindirmelerle yaratıcı bir biçimde kullanılmıştır. Tüm bunlara rağmen kameranın statik konumu değişmemiştir. Sinema tarihi içerisinde seyircinin sabit konumunun dönüşmesi, ancak kameranın hareket kabiliyetinin artışı nedeniyle bakış noktalarının çoğalması ile sağlanabilmiştir.

Kamera kullanımında ana sorun kameranın nereye konacağıdır çünkü kameranın yeri öyküyü anlatma biçimini değiştirmekte, seyircinin ne ve nasıl gördüğünü belirlemektedir. Bu süreçte seyircinin gördükleri kadar görmedikleri de önem arz etmektedir. Tarihsel açıdan Griffith kamerayı sabit yerinden kurtarıp hareketlendirmiştir. Kamera, sinemanın ilk dönemlerinde genellikle araba ya da tren üzerine konarak hareket ettirilmiş, ardından vinç kullanımı başlamıştır. Ancak kamera hareketlerindeki esas dönüşümü sağlayan stedikam ${ }^{6}$ olmuştur (Brown, 2014, s. 210). Her hareketle birlikte kamera yeni bir konum ve bakış açısı kazanmaktadır. Kameranın teknik yeterliliklerinin olmadığı ilk dönemlerde ise her şey sabit bir düzlemde tiyatro seyircisinin konumuyla örtüşmüştür.

Tiyatroda seyircinin gözü ve kulağı ile tecrübe ettiği arasında fark yokken filmde pek

6 Stedikam, kurulu bir zemin üzerinde hareket ettirilmek zorunda olan kamerayı özgürleştirerek her şart altında kullanılabilir kılmıştır. Stedikam gibi teknolojik gelişmeler insanın bakış pratiklerini değiştirmektedir. Ancak stedikam fazlasıyla teknolojik bir gelişme olduğu ve makalenin sınırlarını aştığı için detaylı bir biçimde ele alınmayacaktır. Daha detaylı bilgi için Gustavo Mercado'nun Sinemacının Gözü (2018) metnindeki "Stedikam Planı" adlı bölüme bakılabilir. 
çok yöntem vardır. Sinema alanıyla ilk uğraşan tiyatrocular kamerayı sadece seyirciyi çoğaltmanın bir aracı gibi düşünüp seyircinin olduğu yere koyarak kaydettiler. Filmi izleyen seyirci ile tiyatro seyircisinin konumu örtüşerek film tek bir bakış açısından gösterildi. İlk filmlerde kameranın yeri değiştirilmediği için bakış açısı sabitti ve bu filmler tiyatroya benziyordu ama tiyatronun sahip olduğu doğrudanlık ve kişisel deneyimden yoksundu. Dolayısıyla sinema tarihi "sinemasal" denilen tekniklerin ve yöntemlerin gelişimi ile ilişkilidir. Bu yöntemler çerçeve, objektif, ışık ve renk, hareket ve bakış açısı gibi icatlarla alakalıdır (Brown, 2014, s. 14).

İlk filmlerde kameranın hareketsizliği ve mesafenin hep aynı kalmasından ötürü seyircinin mekân içerisindeki konumu ve bakış pratikleri pek değişmemiştir. İtalyan tipi tiyatro sahnesinde olduğu gibi tek bir bakış açısı yani izleme noktası vardır. Kameranın fiziksel ağılıklarından kurtulup daha hafif bir araca dönüşmesi ile kamera seyircinin konumuyla çok daha gerçekçi bir zeminde buluşmakta, hareket ve sahicilik kazanmaktadır. Kameranın hareket etmeye başlaması ile artık dışsallaştırımış mekânın yerine içine girilebilen, farklı açılardan görülebilen ve yeni bir bakış deneyimine imkân tanıyan sürece geçilmiştir. Burch'un ifadesiyle 1905-1920 yılları arasında kameranın oyuncunun yanına gelmesiyle birlikte, "sahne önü mekânı" parçalanmıştır (Burch, 1994, s. 124). İtalyan tipi sahne artık sinemadaki merkezi konumunu kaybetmekte ve seyircinin bakış pratikleri durağanlıktan kurtularak hareketlilik kazanmaktadır. Benzer bir durumu Roy Armes şu şekilde ifade etmektedir:

\begin{abstract}
"Hem kübistler hem de sinemacılar gerçekliği algılayışın yeni bir tarzını yaratmaya ve tek bakış açısını (resimde perspektif; filmde en avantajlı noktaya yerleştirilmiş kamera) yıkarak sanatsal etki elde etmeye çalıştılar. Durumlara ve nesnelere eşzamanlı olarak birkaç açıdan yaklaşıp, parçalı imgeleri yeni bir sentez içinde birleştirerek (nesneyi aynı resim içinde hem önden hem de profilden resmetme; tek bir film sahnesini çözümlemek için genel çekim, orta çekim ve yakın çekimi kullanma) zaman ve uzam arasında, nesnelerin kendileri arasında ve nesnelerle ortaya çıkan yapıta (resim ya da film) yeni bir tarzda bakması istenen izleyiciler arasında yeni ilişkiler kurdular" (Armes, 2011, s. 192).
\end{abstract}

Sinemada konuya istenilen uzaklıktan bakmanın ve uzaklığı değiştirmenin mümkün olmasıyla birlikte tiyatrodan belirli ölçülerde uzaklaşılmıştır. Tiyatroda ise seyirci, olaylara hep belirli bir mesafeden bakmaktadır. Sinema bu sınırı ve mesafeyi kameranın hareketi ile ortadan kaldırmaktadır. Kameranın hareket etmeye başlaması sadece sahneyi hareketlendirmez; aynı zamanda farklı görüş noktaları ve açılar sağlamaktadır. Uzaklığı ve açıları değiştirebilmenin en büyük getirilerinden biri her varlığı farklı bir görünüşle seyirciye sunabilmektir. Seyirci, tiyatro seyircisi gibi hiç kımıldamadığı halde, kameranın hareketi ile önündeki varlıkları farklı boyutlardan ve açılardan görme imkânına kavuşmaktadır (Özön, 2008, s. 75, 85).

Tiyatroda seyircinin ne konumu ne de bakış noktaları değişme imkânına sahiptir çünkü sahnenin ve seyircinin bulunduğu yerin değişmesi söz konusu değildir. Hâlbuki kamera mesafeyi, sınırı, içerisini ve dışarısını hareketi ile dönüştürmekte ve tiyatronun klasik yapısının dışına zamanla sinematografik unsurlar sayesinde çıkmaktadır. Mesela nesneyi genel ya da yakın çekimle kayda almak birbirinden çok farklı bakış biçimleri açığa çıkartmakta ve seyircinin konumunu belirlemektedir. Kameranın hareket kazanması, mekânı ve nesneyi hem içeriden hem de dışardan kuşatmasına ve seyircinin bakış açılarını çoğaltmasına neden olmaktadır. Burada önem arz eden 
diğer husus kameranın teknik açıdan yetkinleşerek hayatın her alanına dâhil olması ve görüntüleyemediği ya da kadrajına alamadığı hiçbir nesnenin kalmamasıdır. Göz olarak kameranın maddi dünyayı kaydederek kuşatması, her yere girebilmesi, farklı mekânlar arasında ve içerisinde rahatlıkla hareket edebilmesi ve bakış noktalarını çoğaltması bağlamında Dziga Vertov'un 1929 yılında çektiği "Film Kameralı Adam" filmi incelenecektir.

\section{Film Incelemesi: Film Kameralı Adam}

Siegfried Kracauer "Film Kameralı Adam" filminden hareketle, kamera ile ilgili olarak şunları ifade etmektedir: Kamera gündelik hayatın içerisine dalar ve normal akışı kesintiye uğratır. Bazen ağır çekim bazen de yakın çekimle nesnelerini keyfince inşa eder. Hayatın olağan devinimi bazı sahnelerde dondurulur; hareket halindeki kalabalık bir anda durdurulur (2008, s. 45-46). Kracauer'in değindiği noktalar sadece Film Kameralı Adam'a özgü değildir çünkü her film içerisinde benzer eylemler gerçekleştirilebilir ve filmin sağladığı teknik imkânlar doğrultusunda değiştirilebilir. Ancak Film Kameralı Adam'ı ayırt edici kılan husus belgesel niteliğinde bir yapıt olarak kamerayı sokağa çıkarması ve gündelik hayatın her anına ve alanına sızarak nesnesini kaydetmesi, şekillendirmesi ve maddi dünyayı görüntü düzleminin nitelikleriyle doğru orantılı bir biçimde yeniden var etmesidir.

Filmin yönetmeni olan Vertov açısından sine-göz hem mekânı hem de zamanı fethetmekte; ayrı unsurları görsel açıdan birbirine bağlamaktadır. Sine-göz için ne duvarlar ne de mesafeler engel oluşturmamaktadır (Vertov, 2007, s. 104, 148). Kamera artık özgürlük alanı olarak açığa çıkmakta, her yere ulaşabilmekte, mahremiyet olgusunu dönüştürmekte, mesafeyi ortadan kaldırmakta; özellikle de insanın gözü üzerinde yönlendirici bir güce sahip olmaktadır. Vertov kamerayı teknolojik donanımları sayesinde gözün mekanikleşmiş ve yetkinleşmiş bir versiyonu olarak kabul etmektedir. İnsanın gözleri geliştirilemez ama kamera kusursuzlaştırılabilir. İnsan gözü zayıftır ve göz kameraya boyun eğmektedir. Sine-göz, mekanik bir gözdür ve dünyayı mekanik gözün gördüğü şekilde sunmaktadır hatta gözün görmediklerini hem görmekte hem de göstermektedir (2007, s. 16, 18, 47). İnsan gözünden daha kusursuz olan kamera ya da sine-göz ile her şey araştırıldığı, kayıt altına alındığı ve detaylarına vakıf olunduğu için kameralı adam da bir makine gibi hareket etmektedir.

Kamera vasıtasıyla sinemanın yakaladığı hareket olgusu herhangi bir insanın normal şartlar altında elde edebileceği bir şey değildir. Ancak kamera ile her türlü mekân içerisinde hareket edilebilmekte ve her yere ulaşılabilmektedir. Sinema, bir koltuğa oturan ve konumu hiç değişmeyen seyirciyi kamera aracılığıyla hareketlendirmektedir. Virilio'nu ifadesiyle sinema, hareket etmeyen seyircinin bakışına "yeni bir enerji" getirmektedir (Virilio, 2003, s. 26). Bu durum insanın tecrübesi açısından bir ilki oluşturmaktadır çünkü konumu değişmemekle birlikte bakış noktaları çoğalmaktadır. Mekanik göz olarak kamera, gözden daha yetkin bir biçimde gündelik hayatın içerisindeki her şeyi görüntülemekte ve süreç boyunca seyircinin fiziksel konumu hiç değişmemekte ama bakışı çok canlı bir hale gelmektedir. Sinemada kameranın yarattığı 
bu hareketlilik, Vertov'un bedensizleşmiş "sinema göz"ünün her yere girebilmesini ve her şeyi görebilmesini sağlamaktadır.

"Sinemasal lens, başından itibaren, sık sık bir protez göz gibi işlev görerek insan algısının mekanik bir uzanımı olma amacına hizmet etti. Bir yüzyı öncesinin büyük ölçüde hava ulaşımı ve özel otomobillerden yoksun dünyası, ulaşımın kolayca elde edilebilir mekanikleştirilmiş yöntemi olarak yalnızca demiryolunu biliyordu. Sinema bu dünyaya engin bir esnekliğe sahip, dizginlenemez bir mobil göz olarak daldı: artık beden bağlı olmayan ve mekanik buluşlar sayesinde özgürce dolaşıp seyahat edebilen, pratikte görünmez olabilen, (özel olsun, toplumsal olsun, fiziksel olsun) hemen hiçbir yere girmesi engellenemeyen, yalnızca her yerde bulunmakla kalmayan ... zaman yolculuğunu da mümkün kılan bir organa sahip olmak ne denli kıvanç doğurmuştur kim bilir" (Elsaesser ve Hagener, 2014, s. 161-162).

Mekanik göz belirli bir yerde oturmakta olan insanı hareketlendirmekte ve dünyanın her yerini ulaşılabilir kılmaktadır. Ulaşım araçlarının sağlayamadığı hızı bir kitle iletişim aracı olarak sinema sağlamakta ve bedensiz bir biçimde hareketi kolaylaştırmaktadır. 19. ve 20. yüzyılın idealleri kameranın hareket yetilerinin gelişmesi ile doğru orantılı bir biçimde gerçekleşme imkânı bulmuştur. Sinema vasıtasıyla kamera, insan gözünü mekanize etmenin dışında, bir gözün yapabileceklerini daha da ileriye taşıyarak insanın dünyayla kuracağı ilişkiyi de dönüştürmektedir. Bu ilişkinin teknolojik determinizmin sınırlarını belirli ölçüler içerisinde aşan ama ekonomik, sanatsal, kültürel, toplumsal ve siyasal bazı sonuçlarına da değinmek gerektiği için Walter Benjamin ile Adorno ve Horkheimer'ın düşüncelerine yer verilecektir.

Benjamin, Tekniğin Olanaklarıyla Yeniden Üretilebildiği Çağda Sanat Yapıtı adlı makalesinde teknolojik araçların sanat alanındaki yeniden-üretim pratiklerini nasıl değiştirdiğini, sanat eserinin aurasını/halesini kaybettiğini ama toplumsal açıdan da demokratikleştiğini ifade etmektedir. Teknik aracılığıyla yeniden-üretilen sanat yapıtı, şimdi ve burada'ığı ile biricikliğini yitirmektedir. Özgün yapıt, kopyalarının üretimi ile hem hakiki değerinden hem de özel atmosferinden sıyrımaktadır. Yeniden-üretilen her eser, orijinal bağlamını yitirerek alımlayıcısına bulunduğu zaman ve konum içerisinde seslenebilmektedir. Kitleler açısından her türlü nesnenin uzamsal açıdan yakınlaştığı ve farklı kopyaları elinin altında bulundurabildiği bir süreç yaşanmaya başlamıştır. Sanat yapıtının teknik yoldan yeniden-üretimi, onun sergilenme imkânlarını da sonuna kadar genişletmiş, sanat eseri geniş kitlelere ulaşmış ve yağlıboya tablonun klasik dönemdeki sınırlı sayıdaki seyircisi ortadan kalkmıştır. Bu süreç öyle bir noktaya gelmiştir ki, herkes bir sinema filminin figüranına dönüşebileceği gibi okur da her an bir yazara dönüşebilmektedir. Artık insanlık kendisi için bir sergi malzemesi haline gelmiştir (2012).

Benjamin'in düşüncelerinden hareketle kamera, insan elini aradan çıkararak hem birebir kopyalamanın imkânlarını hem de hızını artırmıştır. Kamera ve fotoğraf ile maddi dünyanın avuçlanabilir ve ele geçirilebilir bir olguya indirgenmesi yağlıboya tabloya göre çok daha kuvvetli bir biçimde sağlanmıştır. John Berger'in neredeyse Rönesans sonrası tüm resim tarihini sahiplik ilişkisi üzerinden okuduğu düşünüldüğünde teknik aygıtların bu durumu daha radikal bir seviyeye getirdiği görülmektedir. Benjamin, tartışmasının merkezine teknolojik bir araç olarak kamerayı koymakta ve onun yenidenüretim pratiğini sanat alanında tartışmaktadır. Hâlbuki kamera sadece sanatsal 
nesneyi yani objeyi kopyalamakla sınırlandırılamaz çünkü bu makalenin vurguladığı ve Vertov'un filminde de görülmeye başlanan şey, kameranın hareket yetilerinin artması ile gündelik hayatın tamamına dâhil olabilmesidir. Bu bağlamda ilk yeniden-üretim aracı olan kamera, maddi dünyaya ait her türlü fenomeni nesneleştirerek kadrajına alabilmekte ve fotoğraflayabilmektedir.

Yeniden-üretim olgusunun kültürel alandaki farklı bir karşılığı da kültür endüstrisi kavramsallaştırması ile Adorno ve Horkheimer tarafından ifade edilmiştir. Kültür Endüstrisi adlı makalelerinde tüm kültürel unsurların bütüncül bir yapı oluşturduğunu ve sinemadan radyoya her parçanın bütüne hizmet ettiğini vurgularlar. Kültür endüstrisi içerisinde herkese uygun tüketilecek bir ürün vardır; tüketiciler basit birer istatistik malzemesidir ve boş zamanlarında bile tüketme vazifelerini yerine getirmek zorundadırlar. İzleyicinin algılama süreçleri de kısaltılarak anlık görüntülerin hızına ayak uydurması istenir. Bu süreçte kültür nesneleri, insanların kataloglanmasını ve sınıflandırılmasını sağlar. Hiçbir şeyin olduğu gibi kalmadığı ve akıp gittiği düzen, mekanik yeniden-üretimin başarısıdır. Hafif sanat ile ciddi sanat ya da eğlence ile sanat gibi ayrımlar da ortadan kaldırılır. Kültür endüstrisi seri yeniden-üretim ile her türlü gereksinimi üretebilir, belirleyebilir ve denetleyebilir. Düzen içerisine dâhil edilen herkese bir şeyler sunulur; her film bir sonraki filmin fragmanına dönüştüğü gibi her kültürel ürün de bir diğer ürünün tamamlayıcısı olur (2010).

Kültür alanında herkese uygun tüketilecek bir "eser"in üretimi teknolojik aygıtların seri üretim ve çeşitlendirme (diversification) mantığı ile gerçekleştirilmektedir. Yağlıboya tablo çok uzun yıllar boyunca seri yeniden-üretimin konusu ol(a)madı; ancak fotoğrafın varlığı ile resmin kopyaları üretilmeye başlanmıştır. Böylece fotoğraf, ekonomik çıktılar açısından kapitalizmin, toplumsal çıktılar açısından da iktidarın ihtiyaçlarını karşılamıştır. Burada makalenin sınırlılıkları açısından önem arz eden esas nokta teknolojik aygıtlar vasıtasıyla yeniden üretimin kültür alanında sağlanabilmesi ve kitlelere servis edilebilecek sayıda eserin kopyasının üretilebilmesidir. Bu süreçte kameranın, fotoğraf ve sinema alanında yaptıklarına bakıldığı takdirde ciddi dönüşümlerin yaşandığı görülmektedir. Sinema, fotoğraf kamerasının fiziksel sınırlarını aşarak herhangi bir olgunun öncesiyle ve sonrasıyla farklı görüş noktalarından kayıt altına alınabileceği yeni bir durum yaratmıştır.

Kamera görünür olan her şeye ve dünyaya dâhil olarak, inceleyerek ve kaydederek hem olanı hem de olması bekleneni hesaplamaktadır. Kamera her türlü olayı kendi bilinmezliğinden çıkartıp aydınlığa kavuşturmayı sağlamaktadır (Vertov, 2007, s. 8283). Bu bağlamda yakın çekimlerin varlığı çok büyük bir önem arz etmektedir çünkü insanın dahil olamayacağı mekânlar ve o mekânlar içerisindeki nesneler ancak yakın ve detay çekimler ile gösterilmekte ve fark edilmesi sağlanmaktadır.

Yakın çekimler sadece filme özgü bir unsur olarak kullanılarak hareketin içerisindeki bir parçayı büyütebilmektedir. Sahnenin içinden seçilen bir insan, nesne ya da surat, yakın çekim ile tüm görüntüyü kaplamaktadır. Normalde bu unsurlara sabit bir uzaklıktan bakılabilirken, yakın çekim, parçaları ayrıntılı bir biçimde göstermektedir. Yakın çekimde seyirci sahneye dâhil olmakta, gereksiz unsurlar dışlanmakta ve vurgu tek bir yerde toplanmaktadır (Mascelli, 1965, s. 173). Yakın çekim genellikle elleri, 
ayakları ve küçük nesneleri göstermektedir; yüzdeki bir jesti ya da önemli bir nesneyi ön plana çıkartmaktadır (Bordwell ve Thompson, 2012, s. 195). Yakın çekimlerin tercih edilme nedeni sahne içerisindeki detayları göstererek seyircinin odağının dağılmasını engellemek ve devasa bir şehir içerisindeki küçük parçaları ön plana çıkartmaktır. Film Kameralı Adam da tanımlanmış bu amaçlar doğrultusunda genel çekimler yerine yakın çekimlerle başlayarak önceliği kentte görülemeyecek ya da görülse bile fark edilemeyecek detaylara vermektedir. Film birçok eşyanın yakın çekimi ile başlar, sonrasında bir evin içerisine girer; sokakları, farklı farklı insanları ve mekânları gösterir. Her yer boş, sessiz ve hareketsizdir. Bu unsurlar gösterilirken kamera hareket ettirilmediği için geçişler kesmeler aracılığıyla sağlanmaktadır. Kente ait her türlü detay genel olarak yakın çekimlerle vurgulanmakta ve kayıt alına alınmaktadır.

Arabalar, tekerlekler, binalar gösterilmeye devam ederken kamerasıyla binayı terk eden kameralı bir adama kesme yapılmaktadır. Bu süreçten itibaren kamera hareketlenmeye ve hayatın her alanına ve anına iyice dâhil olmaya başlamaktadır; sınırlar kamera vasıtasıyla ortadan kalkmaktadır. Hiçbir şey kameradan kaçamamakta; hayata ait tüm unsurlar kadraja girerek çerçevelenmekte ve modernlik ile uyumlu bir biçimde kayıt altına alınmaktadır.

Vertov kameraya ve konumuna büyük bir önem atfettiği için film içerisinde kamerayı hem görünür kılmakta hem de her yere yerleştirmektedir. Kamera her şeye muktedir bir rol oynadığı gibi hayatın da dışında değil içinde yer almaktadır; neredeyse hiçbir olay mekanik gözden kaçamamaktadır. Filmin stüdyoda değil de sokaklarda çekiliyor olması da gündelik gerçekliği kayıt altına alma arzusu ile ilgilidir. Kameralı Adam her yeri kuşatarak kaydetmekte; bireysel ve toplumsal olan arasındaki sınırı müphemleştirerek kayıt altına almakta ve bir yandan da seyircinin bakışını farklı dünyalara dahil ederek hareketlendirmektedir. Kamera, mekanik göz olarak bedensiz olduğu için her yere rahatlıkla girip çıkabilmektedir. Mekanik gözün varlığı ile insanın mekansal sınırları geniş̧lediği ve ulaşamadığı hiçbir yer kalmadığı gibi gözünün sınırları da aşılarak yeni özellikler kazanmaktadır.

Film boyunca kamera ile insan gözünün birbiriyle iç içe geçtiği anlarda karşılaştırmalar ve benzetmeler kullanılmaktadır. Vertov'a göre mekanik göz olan kamera ile insan gözü ne kadar birbirine benzese de kamera daha yetkindir ve hareket serbestisi fazladır. Daha önce de değinildiği gibi yakın çekimler vasıtasıyla mesafe ortadan kaldırılmakta ve nesneye istenildiği kadar yakınlaşılabilmektedir. Mekanik gözün hareketlenmesi her yeri yakın kılmakta ve uzaklığı sorun olmaktan çıkartmakta ve klasik tiyatro seyircisinin konumunu ortadan kaldırmaktadır. Gün doğumundan sonra kent iyice hareketlenmekte ve mekanik göz kesmeler vasıtasıyla bunları kaydetmektedir. Kalabalıklar, koşuşturan insanlar, özellikle de fabrikalar ve mekanik araç gereçler yakın çekimler ile sunulmaktadır. Filmde birçok kez kente tepeden bakılan sahneler vardır; genel çekimler vasıtasıyla mekân parçalanmadan bir bütün halinde kuşatılmaktadır. Filmin başından beri aslında yakın çekimler ile belirli parçalarının görüldüğü mekan, kentin tepesinden gerçekleştirilen aşırı genel çekimlerle de (extreme long shot) seyirciye bütünlüklü bir biçimde gösterilmektedir.

Genel planlarda mekanın boyutları belirtilmektedir; insanlar çok küçük gözükmektedir; 
mekan vurgulanmakta ve ana olayla seyirci arasında ciddi bir mesafe söz konusu olmaktadır. Aynı zamanda genel planlar çok fazla görsel bilgi barındırdığı için seyircinin de anlamak için daha fazla zamana ihtiyacı vardır (Mercado, 2018, s. 81). Aşırı genel çekimlerde de benzer biçimde nesneler çok küçülmekte ve manzara ya da insan kalabalığı ekranı tamamen kaplamaktadır (Bordwell ve Thompson, 2012, s. 490). ${ }^{7}$

Kameranın şehri kuşattığı aşırı genel çekimler bu amaçlar doğrultusunda kullanılarak mekânla yeni ve farklı bir ilişki biçimi geliştirilmektedir. Kentin her alanı mobil göz olan kamera ile taranırken, bir yandan da tepe noktalardan yapılan çekimlerle kentin üzerine silah gibi doğrultulmaktadır. Kameranın silah olarak gösterimi, maddi dünyanın görüntü düzleminde ele geçirilmesi ile ilişkili bir biçimde okunmalıdır; her şeyi kayıt altına alan ve her şeyden haberdar olan bir araç olarak kamera tehdit edici bir boyuta sahiptir.

Kameranın hareketini sağlayabilmek için sinemanın ilk dönemlerinin klasik bir örneği olarak at arabasının üzerine konmakta ve kameranın hızlı hareketi böylece sağlanmaktadır. Kamera o kadar çok yer değiştirmeye ve bakış açılarını çoğaltmaya başlar ki bulunduğu mekânlar insanların doğum ve ölüm anlarını bile kuşatmaktadır. Film ilerledikçe kamera mutlak bir konuma sahip olarak her unsuru ele geçirmekte; evlenen, boşanan ve ağlayan insanları göstermektedir. Sırtında kamerasıyla kentin her yerini dolaşan ve her yere dahil olan film kameralı adam ile tüm gündelik pratikler kayıt altına alınmakta, birçok kez olduğu gibi bazen kentin tepe noktalarında çekim yaparken görüntülenmektedir.

Sonrasında çok hızlı kamera çevrimleriyle hem nerede olunduğu hem de neyin görüldüğü belli olmaz. Sahneler büyük bir hızla kesilerek birbirine bağlandığı için seyirci görüntüleri algılamakta zorlanmaktadır. Sahneler arası geçişler o kadar hızlanır ki, Vertov bu anları makinelerin hızlı hareketleri ile örtüştürerek sinemanın teknolojik bir aygıt olmasına vurgu yapmaktadır. Görüntüler arasındaki hızı geçişler insan gözünün algılama imkanını aşan bir durum yaratarak, mekanik gözün yetilerinin insanın gözünden daha üstün olduğunu göstermekte ve çok hızlı kesmeler vasıtasıyla görüntülerin anlaşılamayacağı bir seviyeye getirilmesiyle film bitmektedir. Gündelik hayata dahil olan Film Kameralı Adam, insanın bakış noktalarını çoğaltmakta, sınırlarını genişletmekte, mesafeyi ortadan kaldırmakta ve maddi dünyayı kayıt altına almaktadır.

\section{Sonuç}

İnsan gözünün uzantısı gibi bir işleve sahip olan kamera, dünyayı insanın bilgisine açarken bilinmedik ve kayıt altına alınmadık köşe bucak bırakmamaktadır. İnsan, gözü vasıtasıyla elde edemeyeceği her niteliği kamerayla elde etmekte; dünyayı ve nesneleri ele geçirme noktasında modernliğin amaçlarıyla örtüşmektedir. Sinemada

7 Bu ve benzeri çekim ölçekleri sadece mekânsal değil zamansal çıktılara da sahiptir. Genel çekimlerin çok büyük bir bilgi yığınına sahip olması nedeniyle seyirci, bu çekimleri anlamak için daha fazla zamana intiyaç duyar. Yakın çekimler ise çok az unsuru içerisinde barındırdığı için sadece belirli nesnelere vurgu yaparak anlamlandırma sürecini kısaltır. Daha detaylı bilgi için bkz. Demir, Y. (1994b). Filmsel Zamanın Yaratılmasında Filmsel Araçların Zamanı Etkilemedeki Rolleri. Y. Demir (Ed.). Filmde Zaman ve Mekan içinde. Eskişehir: Turkuaz Yayınları, 1994, 47-69. 
maddi dünya her türlü fiziksel boyutunu kaybederek farklı bir zeminde yani görüntü bağlamında var oluş imkânı kazanmaktadır. Maddi olanın yerini alan görüntüler modernliğin amaçlarından sapmayı değil, aksine modernlikle uyumlu bir yapıyı inşa etmektedir. Modernliğin her türlü fenomeni sayısallaştırarak tanımlayan, açıklayan ve parçalarına bölen tavrı ile mekanik gözün kayıt altına aldığı maddi dünyanın görüntüleri arasında doğrudan bir ilişki vardır. Çünkü görüntüler de modernlik gibi kayıt altına aldığı her fenomeni nesneleştirmektedir. Bu süreçte kameranın hareketlilik kazanması ile bakış açıları çoğalmakta, Rönesans perspektifine dayalı bakış pratiği zarar görmekte ve nesneyle çok daha sahici bir ilişki kurulmaktadır.

Mekanik göz inanılmaz derecede esnek ve hareketli bir yapıya sahip olarak insan bedeninin ve gözünün zaaflarını bir kenara atmakta; bedene ve göze ihtiyaç duyulmayan bir noktaya gelindiği için iktidar duygusu da yaratmaktadır. Bedensizleşme, mekanik gözün hareket alanını arttırdığı için mesafeler engel olmaktan çıkmakta ve farklı mekânlar arasında özgürce dolaşabilmektedir. Her yerde bulunabilen kamera, dünyayı ve nesneleri hammadde haline getirmekte ve istediği şekiller içerisinde kullanabilme imkânına kavuşmaktadır.

Bu bağlamda sinemada her şey önceden belirlenmekte ve kurgulanmakta; organik düzen yerini mekanik bütünlüğe bırakmaktadır. Her şeyin kayıt altına alınarak düzenlenmeye çalışıldığı bir düzende kameranın hareket kabiliyetinin ve bakış açılarının çoğalmış olması ile hem mekânı hem de nesneyi çok daha iyi ve gerçekçi bir biçimde kuşatabilir hale geldiği görülmektedir. Bu olgu Film Kameralı Adam filminde çok açık bir biçimde uygulanmıştır.

Sinemada kamera vasıtasıyla gözün istenildiği gibi kurgulanma, manipüle edilme ve yeniden şekillendirilme imkânı mevcuttur. Film Kameralı Adam filmi gözü, mekanik göz aracılığıyla gündelik hayata dâhil ederek her türlü nesneye yakınlaştırmakta ve görme biçimleri yakın ve uzak çekim gibi sinematografik unsurlar üzerinden inşa edilmektedir. Yakın çekimler ile birçok detay ön plana çıkartılabilirken, genel çekimlerle de detay yerine bütüne odaklanılmakta ve seyircinin bakışı istenildiği gibi yönlendirilmektedir. Mekanik göz, maddi dünyayı perspektiften ve tiyatro seyircisinin konumundan çok daha farklı şekillerde göstermektedir. Nesnel kamera, yakın ve genel çekimler bunlara örnek olarak verilebilir. Kameranın hareketlenmesi ile sadece bakış değil her şeyin konumu, özellikle de dünyayla kurulan ilişki değişmektedir çünkü tek ve merkezi bir bakış açısı yerine dünyayı farklı açılardan gösterme imkânı doğmuştur. Bu süreçte Vertov'cu sine-göz de kameranın yetkinleşerek insanın gözünü aşmasını olumlamakta ve gündelik hayatın her anına ve her alanına dâhil olmaktadır.

Sonuç olarak kamera vasıtasıyla sinema, maddi dünyaya hâkim olmanın, nesneler üzerinde istenildiği gibi oynamanın imkânını sağlayarak kendine has yeni bir dünya yaratmakta, ele aldığı her unsuru daima kendisine ait kılarak mekanik düzen içerisinde kaydederek görüntülemektedir. Bugün, özellikle dijitalleşmenin etkilerinin artışı ile birlikte mekanik gözün sadece maddi dünyayı değil, aynı zamanda maddi olmayan her unsuru sinemanın nesnesi kılabildiği yeni bir süreç yaşanmaktadır. Maddi olanın neredeyse önemsizleştiği ve mekanik düzenin bir getirisi olarak nesnenin tamamen yapay ortamlarda üretildiği bu yeni bir durum incelenmeyi beklemektedir. 


\section{Kaynakça}

Adorno, T. W. ve M, Horkheimer. (2010). Aydınlanma’nın Diyalektiği. (N. Ülner ve E. Ö. Karadoğan, Çev.) İstanbul: Kabalcı.

Andrew, D. (2010). Büyük Sinema Kuramları. (Z. Atam, Çev.) İstanbul: Doruk Yayınları.

Armes, R. (2011). Sinema ve Gerçeklik. (Z. Ö. Barkot, Çev.) İstanbul: Doruk Yayımcılık.

Arnheim, R. (2010). Sanat Olarak Sinema. (2. b.). (R. Ü. Tamdoğan, Çev.) İstanbul: Hil Yayınları.

Bağce. H. E. (2004). Modernliğin Temelleri ve İkircikli Serüveni. Modernlik ve Modernleşme Sürecinde Türkiye içinde. Ankara: Babil Yayınları, 2004, 3-59.

Barthes, R. (2011). Camera Lucida. (5. b.). (R. Akçakaya, Çev.) İstanbul: Altıkırkbeş Yayın.

Baudrillard, J. (2005). Anahtar Sözcükler. (O. Adanır, ve L. Yıldırım, Çev.) Ankara: Paragraf Yayınları.

Baudrillard, J. (2012a). İmkansız Takas. (2. b.). (A. Sönmezay, Çev.) İstanbul: Ayrıntı Yayınları.

Baudrillard, J. (2012b). Sanat Komplosu. (4. b.). (E. Gen, ve I. Ergüden, Çev.) İstanbul: İletişim Yayınları.

Baudrillard, J. (2013). Simülakrlar ve Simülasyon. (7. b.). (O. Adanır, Çev.) Ankara: Doğu Batı Yayınları.

Benjamin, W. (2012). Pasajlar. (9. b.). (A. Cemal, Çev.) İstanbul: Yapı Kredi Yayınları.

Berger, J. (2012). Görme Biçimleri. (18. b.). (Y. Salman, Çev.) İstanbul: Metis Yayınları.

Burch, N. (1994). Zaman ve Mekân Ille İlgili Bağlantılar. Y. Demir (Ed.). Filmde Zaman ve Mekan içinde (Y. Demir, Çev.) Eskişehir: Turkuaz Yayınları, 1994, 117-130.

Bordwell, D. ve K, Thompson. (2012). Film Sanatı. (2. b.). (E. Yılmaz, ve E. S. Onat, Çev.) Ankara: De Ki Yayınları.

Brown, B. (2014). Sinematografi: Kuram ve Uygulama. (4. b.). (S. Taylaner, Çev.) İstanbul: Hil Yayınları.

Capra, F. (2018). Batı Düşüncesinde Dönüm Noktası. (4. b.). (M. Armağan, Çev.) İstanbul: İnsan Yayınları.

Çitil, A. A. (2017). Selefiliğin Çözümlenmesi İçin Bir Anahtar: Modern Bilimlerin Gelişiminde Kuram-Gözlem Bağıntısının Dönüşümü. Modernleşme, Protestanlaşma ve Selefilik Kongresi. https://www.youtube.com/watch?v=XoUUTmOK_wU (10.04.2019).

Demir, Y. (1994a). Filmde Zaman ve Mekan Üzerine. Y. Demir (Ed.). Filmde Zaman ve Mekan içinde. Eskişehir: Turkuaz Yayınları, 1994, 1-9.

Demir, Y. (1994b). Filmsel Zamanın Yaratılmasında Filmsel Araçların Zamanı Etkilemedeki Rolleri. Y. Demir (Ed.). Filmde Zaman ve Mekan içinde. Eskişehir: Turkuaz Yayınları, 1994, 47-69.

Demir, Y. (1994c). Mercekler ve Perspektif. Y. Demir (Ed.). Filmde Zaman ve Mekan içinde. Eskişehir: Turkuaz Yayınları, 1994, 109-116. 
Derman, İ. (2010). Fotoğraf ve Gerçeklik. (2. b.). İstanbul: Hayalbaz Kitaplık.

Elsaesser, T. ve Hagener, M. (2014). Film Kuramı. (B. Soner, ve B. Yıldırım, Çev.) Ankara: Dipnot Yayınları.

Florenski, P. (2011). Tersten Perspektif. (3. b.). (Y. Tükel, Çev.) İstanbul: Metis Yayınları.

Freund, G. (2008). Fotoğraf ve Toplum. (2. b.). (Ş. Demirkol, Çev.) İstanbul: Sel Yayıncılık.

Harvey, D. (2014). Postmodernliğin Durumu. (7. b.). (S. Savran, Çev.) İstanbul: Metis Yayınları.

Kracauer, S. (2008). Siegfried Kracauer'ın 'Sine-Kent' Denemeleri. M. Öztürk (Ed.). Sinematografik Kentler içinde (Ö. B. Albayrak, Çev.) İstanbul: Agora Kitaplığı, 2008, 43-68.

Mascelli, J. V. (1965). The Five C's of Cinematography. Los Angeles: Silman-James Press.

Mattelart, A. (2005). Gezegensel Ütopya Tarihi. İstanbul: Ayrıntı Yayınları.

Mattelart, A. (2013). Iletişsimin Dünyasallaşması (3. b.). (H. Yücel, Çev.) İstanbul: İletişim Yayınları.

Mercado, G. (2018). Sinemacının Gözü. (2. b.). (S. Taylaner, Çev.) İstanbul: Hil Yayın.

Mumford, L. (1996). Makina Efsanesi. İstanbul: Inssan Yayınları.

Özçınar, M. (2009). Toplumsal Kültürel Zaman Mekân Algııının Anlatı İnşasındaki Yeri ve Örnek Film İncelemeleri. İstanbul Üniversitesi İletişim Fakültesi Dergisi. 37, 88-108.

Özön, N. (2008). Sinema Sanatına Giriş. İstanbul: Agora Kitaplığı.

Pezella, M. (2006). Sinemada Estetik. (F. Demir, Çev.) Ankara: Dost Kitabevi.

Sayın, Z. (2013). İmgenin Pornografisi. İstanbul: Metis Yayınları.

Sontag, S. (2011). Fotoğraf Üzerine. (2. b.). (O. Akınhay, Çev.) İstanbul: Agora Kitaplığı.

Süalp, Z. T. (2004). ZamanMekan - Kuram ve Sinema. İstanbul: Bağlam Yayınları.

Thompson, J. B. (2008). Medya ve Modernite. (S. Öztürk, Çev.) İstanbul: Kırmızı Yayınları.

Touraine, A. (2016). Modernliğin Eleştirisi. (10. b.) (H. U. Tanrıöver, Çev.) İstanbul: Yapı Kredi Yayınları.

Trusted, J. (2018). Fizik ve Metafizik. (3. b.). (S. Yılmaz, Çev.) İstanbul: İnsan Yayınları.

Yaykın, M. (2011). Fotoğraf ideolojisi: "algıda gerçeğin bozulumu". (2. b.). İstanbul: Kalkedon Yayınları.

Vertov, D. (2007). Sine-Göz. (A. Ergenç, Çev.) İstanbul: Agora Kitaplığı.

Virilio, P. (2003). Enformasyon Bombası. (K. Şahin, Çev.) İstanbul: Metis Yayınları 


\section{Extended Abstract \\ Physcial World as a Record of the Mechanic Eye \\ Introduction}

In the current article, the traces of the change caused by modernity in human life in terms of cinema and camera will be followed. Since the history of cinema cannot be considered separately from the Western-centered historical process, it will be examined together with the historical conditions in which it was born and triggered certain changes. In this context, when cinema is mentioned, a relationship with modernity will be established in order to understand the issue more clearly.

All over the world, cinema, which implies its existence regardless of time and place, will be examined with an object or tool-centered view, which is called the sovereignty of the object (Baudrillard, 2012a) and constitutes the main backbone of the article. Cinema as a technological tool, as a way of thinking and living, contributes to the acceptance of modernity worldwide, regardless of its content.

It is possible to find a similar phenomenon in the expression that Armand Mattelart attributed to Georges Meliés in his text called The History of Planetary Utopia: "The World Under Your Hand." (2005, p. 207). Meliés grasped the meaning of cinema shortly after it was invented with this advertisement he printed for Film Production House and emphasized how the world was captured by camera.

\section{The Meaning of Modernity and the Position of Cinema}

By the mid-seventeenth century there were beliefs that the material world was the primary source of scientific research, and human actions, mental and theological explanations were omitted. Mathematics were increasingly linked to certain measurements. Based on the idea that natural philosophy could be based on logic like mathematics, the importance of observation and experiment was increasing (Trusted, 2018 , p. 136-137). There is a very strong relationship between the prominence of the phenomenal and observable and the camera. In line with the positivist beliefs, it is believed that the camera can store the material reality, that is, what can be captured, by recording and replaying it over and over again.

When mass media and cinema are read from this context, they come to the fore as tools that determine position of human in the world. Cinema, as a technological tool rather than its artistic qualities, was invented in the West and not elsewhere in the world.

\section{Increasing Point of Views with Moving Camera}

In the theater, neither the position of the audience nor the point of view has the opportunity to change because the stage and the location of the audience are out of the question. However, camera transforms distance, boundary, inside and outside 
with its movement and leaves the classical structure of the theater over time. For example, recording the object in general or close-up reveals very different ways of looking and determines the position of the audience. The movement of the camera causes it to surround the space and the object both from inside and outside, and to increase the viewer's perspective. Another important point here is that the camera is technically competent and included in all areas of life and there is no object left that it cannot display or frame. Dziga Vertov's movie "Man with a Movie Camera", which was shot in 1929, will be examined in the context of the camera as an eye by recording the material world, its ability to enter everywhere, to move easily between and within different spaces, and to increase point of views.

\section{Movie Review: Man with a Movie Camera}

Drawing from the movie "Man with a Movie Camera", Siegfried Kracauer states the following regarding the camera: The camera plunges into everyday life and interrupts the normal flow. He builds his objects arbitrarily, sometimes in slow motion and sometimes in close-up. The usual motion of life is frozen in some scenes; crowd in motion is stopped suddenly (2008, p. 45-46). Man with a Movie Camera, which is included in daily life, increases the point of views of people, expands the boundaries, removes the distance and records the material world.

\section{Conclusion}

As a result, cinema through the camera creates a unique new world by providing the opportunity to dominate the material world, to play on objects as desired, and record and view every element it handles in a mechanical order by always making it its own. 